\title{
Comparative Studies of the Mineral Nutrition of Three Species of Phytophthora
}

\author{
By P. G. FOTHERGILL \\ Department of Botany, University of Nerwcastle-upon-Tyne \\ AND J. H. CHILD \\ Department of Chemistry and Applied Chemistry, Royal College of Advanced \\ Technology, Salford
}

(Received 29 November 1963)

\begin{abstract}
SUMMARY
Nutritional experiments were carried out dealing with: (1) the utilization of sulphur compounds; (2) the utilization of phosphorus compounds; (3) the action of different mineral salts and their interaction. The results showed that Phytophthora erythroseptica grew well at $28^{\circ}$ and $\mathrm{pH} 6.6$ incubated for 20 days; $P$. parasitica grew well at $28^{\circ}$ and $\mathrm{pH} 6.6$ for 17 days; and $P$. infestans at $20^{\circ}$ and $\mathrm{pH} 4.5$ for 16 days. In the adjusted controlled medium $\mathrm{pH}$ changes were generally within one $\mathrm{pH}$ unit. The best carbon and nitrogen sources are stated. The only satisfactory sulphur sources for $\boldsymbol{P}$. infestans were sodium sulphate and sodium thiosulphate. These compounds were also among the best $\mathbf{S}$ sources for $\boldsymbol{P}$. erythroseptica and $\boldsymbol{P}$. parasitica, but a number of other compounds also were utilized equally well, e.g. sodium metabisulphite, sodium sulphite, $\alpha$-cysteine, sodium sulphide, sodium dithionite and methionine. For all organisms the best phosphorus sources were sodium dihydrogen orthophosphate, sodium metaphosphate and lecithin. Rate of utilization of the phosphorus was an important factor in mycelial yield. Factorial experiments were carried out in which $P$. erythroseptica and $P$. parasitica were incubated at $28^{\circ}$ for 17 days. Statistical analysis of the results showed that under the given conditions optimal growth measured as mg. dry wt. was obtained in liquid media containing glucose, $25 \mathrm{~g}$./1.; DL-asparagine, $4.0 \mathrm{~g}$./l.; $\mathrm{FeSO}_{4} .7 \mathrm{H}_{2} \mathrm{O}$, 0.001 g./l.; thiamine, $0.8 \mathrm{mg}$./l.; $\mathrm{ZnSO}_{4} .7 \mathrm{H}_{2} \mathrm{O}, 1$ p.p.m.; $\mathrm{H}_{2} \mathrm{MoO}_{4}, \mathrm{CuSO}_{4}$. $5 \mathrm{H}_{2} \mathrm{O}, 0.02$ p.p.m.; with varying amounts of $\mathrm{K}_{2} \mathrm{HPO}_{4}, \mathrm{MgSO}_{4} .7 \mathrm{H}_{2} \mathrm{O}$ and $\mathrm{CaSO}_{4} \cdot 2 \mathrm{H}_{2} \mathrm{O}$ for the different species specified. There was a balance between all combinations of $\mathrm{K}_{2} \mathrm{HPO}_{4}, \mathrm{MgSO}_{4} \cdot 7 \mathrm{H}_{2} \mathrm{O}$ and $\mathrm{CaSO}_{4} \cdot 2 \mathrm{H}_{2} \mathrm{O}$ for $\boldsymbol{P}$. parasitica but not for $\boldsymbol{P}$. erythroseptica, but there were significant interactions between the salts taken two at a time for both these fungi. There was interaction for all three salts together for both species. Phytophthora infestans and $\boldsymbol{P}$. parasitica are more exacting in their nutritional requirements than $\boldsymbol{P}$. erythroseptica.
\end{abstract}

\section{INTRODUCTION}

Previous work at Newcastle-upon-Tyne (see Fothergill \& Raine, 1954; Fothergill \& Ashcroft, 1955; Fothergill \& Yeoman, 1957; Fothergill \& Jones, 1958; Fothergill $\&$ Hide, 1962) indicated that for some parasitic fungi the balance of the major inorganic salts in a culture medium was more important for the good growth of the mycelium than the concentration of individual salts, but that with some 
saprophytic species the balance was much less important. For a wide range of fungi, however, the results varied. The object of the present experiments was to continue these investigations, with three species of the genus Phytophthora which are usually regarded as facultative parasites having only a short saprophytic existence in the soil. While a large amount of work has been done on these species, particularly $\boldsymbol{P}$. infestans concerning taxonomy, cytology and host-parasite relationships, little comparative work seems to have been done on their mineral nutrition. Earlier experiments, such as those of Payette \& Perrault (1944), were of small value from the nutritional aspect because of the use of undefined media. More exact investigations of these fungi were carried out by Hall (1959), Sakai (1955, 1956) and Mehrotra (1950).

\section{METHODS}

The following organisms were used: Phytophthora infestans (Mont.) de Bary, $\boldsymbol{P}$. erythroseptica Pethybridge and $\boldsymbol{P}$. parasitica Dastur. All of them were obtained from the Central Bureau voor Schimmelcultures, Baarn. Phytophthora infestans is the cause of Late Blight disease of potato; $P$. erythroseptica is a cause of Pink Rot of potatoes, 'shanking' in forced tulips, wilt in Atropa belladonna and other diseases; $\boldsymbol{P}$. parasitica attacks Ricinus communis and causes 'damping off' and 'Foot Rot' of tomato and other plants. Throughout this paper the following abbreviations are used: $\boldsymbol{P}$. infestans is designated PI; $\boldsymbol{P}$. erythroseptica, PE, and $\boldsymbol{P}$. parasitica, PP.

Initially single spore isolates of each of these species were prepared according to the method of Hall (1959) and stock cultures were maintained in $1 \mathrm{oz}$. screw-topped bottles each containing $10 \mathrm{ml}$. French bean oatmeal agar. The stock cultures were stored at $5^{\circ}$ and subcultured at 3-monthly intervals, or when required. No alteration of morphological and cultural characteristics of these fungi occurred during the experimental period. In all experiments cultures were grown in $20 \mathrm{ml}$. medium in $150 \mathrm{ml}$. Erlenmeyer flasks. To avoid caramelization of media, sterilization was carried out at $115^{\circ}$ for $10 \mathrm{~min}$. After the growth period, the mycelia were filtered on to tared Whatman No. 5 filter-papers and washed with water. The mycelium with the filter paper was then dried overnight at $80-85^{\circ}$, cooled in a desiccator and weighed. Results are expressed as mg. dry wt. mycelium/flask, average of 4 or 5 replicates. It was not practicable to separate the mycelium from the filter paper after filtration, and, as the filter papers used lost $5 \%$ of their original weight on drying under the above conditions, appropriate allowances were made. For preliminary experiments the followed basal defined liquid medium $\mathbf{A}$ was used. This was a modification of a medium successfully used by Lopatecki \& Newton (1956) for organisms PE and PP, in which the amounts of glucose and thiamine present were varied as follows: glucose, $25 \mathrm{~g}$./l.; DL-asparagine, $4.0 \mathrm{~g}$./l.; $\mathrm{K}_{2} \mathrm{HPO}_{4}$, 1.0 g./l.; $\mathrm{MgSO}_{4} \cdot 7 \mathrm{H}_{2} \mathrm{O}, 0 \cdot 1 \mathrm{~g} . / \mathrm{l}$; $\mathrm{CaSO}_{4} \cdot 2 \mathrm{H}_{2} \mathrm{O}, 0 \cdot 1 \mathrm{~g} . / \mathrm{l}$; $\mathrm{FeSO}_{4} .7 \mathrm{H}_{2} \mathrm{O}, 0.001 \mathrm{~g} . / \mathrm{l}$; thiamine, 0.8 mg./I.; $\mathrm{ZnSO}_{4} .7 \mathrm{H}_{2} \mathrm{O}$, 1 p.p.m.; $\mathrm{H}_{2} \mathrm{MoO}_{4}, \mathrm{CuSO}_{4} .5 \mathrm{H}_{2} \mathrm{O}$ and $\mathrm{MnSO}_{4} \cdot 4 \mathrm{H}_{2} \mathrm{O}$ at 2 p.p.m. This solution was initially at $\mathrm{pH} 4.7$.

Experiments were made to determine the best method of inoculation. It was found that a minced mycelium technique gave the best and most consistent results, giving a low coefficient of variation between replicate cultures and affording some control over the amount of fungal material added to each experimental flask. In this method, cultures were blended for 10 sec. with $50 \mathrm{ml}$. sterile distilled water in a 
Monel metal container of an 'Atomix' blender. The resulting homogenate was then centrifuged for $5 \mathrm{~min}$. at $3000 \mathrm{rev} . / \mathrm{min}$. in tubes with Oxoid metal caps; the supernatant liquid was discarded and the mycelium was taken up in sterile distilled water. This washing process was repeated three times. The mycelium was finally added to a known volume of sterile distilled water, $10 \mathrm{ml}$. removed and added to an EEL colorimeter tube and the reading recorded. By reference to a previously calibrated graph with a linear scale, the quantity of blended mycelium per ml. could be calculated and the volume of the remainder of the mycelial suspension adjusted to give a concentration of $1 \mathrm{mg}$. of blended mycelium $/ \mathrm{ml}$. water. One $\mathrm{ml}$. of suspension obtained in this way was used as the inoculum in all subsequent experiments.

Preliminary experiments indicated that the optimum temperature for organisms $\mathrm{PE}$ and PP was $28^{\circ}$, and $20^{\circ}$ for PI. These temperatures were used in subsequent experiments. PE grew faster at all temperatures than either PP or PI which had the slowest growth rate. With medium A maximum dry wt. mycelium was obtained with PE after 20 days of incubation, with PP after 13 days, and after 16 days with PI. These incubation times were used in subsequent experiments unless otherwise stated.

Further experiments with medium A showed that glucose, asparagine, $\mathbf{K H}_{2} \mathbf{P O}_{4}$ and $\mathrm{MgSO}_{4} \cdot 7 \mathrm{H}_{2} \mathrm{O}$ were essential nutrients for all three fungi. The omission of $\mathrm{CaSO}_{4} \cdot 2 \mathrm{H}_{2} \mathrm{O}$ from the medium decreased the growth of PE by $70 \%$, of PI by $50 \%$ and of PP by only $7 \%$. The omission of the trace elements had little effect on growth-yield of PP but seriously affected that of the other two species. Omission of $\mathrm{FeSO}_{4} \cdot 7 \mathrm{H}_{2} \mathrm{O}$ had a very marked effect on the yield of $\mathrm{PI}$ and a considerable effect on PP and PE.

The growth of PE and PP in this medium resulted in an increase of acidity as great as 3.5 pH units. The optimum $\mathrm{pH}$ for both PP and PE was 6.6, that for PI was 5.0. Medium A was thus subsequently modified by omission of the initial concentration of $\mathrm{KH}_{2} \mathrm{PO}_{4}$ replacing it with Sorensen's salt adjusted to give $\mathrm{pH} 6 \cdot 6$ (i.e. with $\mathrm{KH}_{2} \mathrm{PO}_{4}, 4 \cdot 746 \mathrm{~g}$./l. $+\mathrm{Na}_{2} \mathrm{HPO}_{4} .2 \mathrm{H}_{2} \mathrm{O}, 5 \cdot 443 \mathrm{~g}$./l.). This medium is referred to as medium $\mathrm{B}$ and was used subsequently for organisms PE and PP. Sorensen's salt at any concentration had a distinctly depressing effect on the growth of PI and medium $\mathrm{A}$ at $\mathrm{pH} 4.7$ was used for this fungus.

Tests showed that none of the fungi needed an exogenous supply of biotin, pyridoxine, nicotinamide, folic acid, riboflavin, calcium pantothenate, $p$-aminobenzoic acid, inositol or ascorbic acid; but thiamine was necessary for good growth. These results confirm those of earlier workers (Robbins, 1937; Cantino, 1955). Preliminary experiments with a wide range of structurally different carbon compounds also showed that the best carbon sources for these fungi were those of similar constitution, namely, sucrose, glucose and mannose for organisms PP and PI, and sucrose, glucose and fructose for PE. Similarly the best nitrogen sources in order of mycelial yield were as follows: for PE glycine, calcium nitrate, cystine, ethyl aminoacetate hydrochloride, histidine, asparagine; for PP aspartic acid, glycine, calcium nitrate, asparagine, $\gamma$-aminobutyric acid, ethyl aminoacetate hydrochloride; and for PI $\gamma$-aminobutyric acid, citrulline, glutamine, arginine and asparagine. 


\section{RESULTS}

\section{Sulphur requirements}

While Mehrotra (1950) made a survey of the sulphur requirements of some species of Phytophthora, the results were criticized by Cantino (1955) because of a lack of $\mathrm{pH}$ control during the growth period. The sulphur requirement of the Phytophthora species used in the present work was thus investigated by varying the sulphur sources individually in media $\mathbf{A}$ and $\mathbf{B}$. The sulphur compounds were each added in turn to these media to give a final concentration of $0.03 \mathrm{~g}$./1. The basal media were modified by the replacement of $\mathrm{MgSO}_{4} \cdot 7 \mathrm{H}_{2} \mathrm{O}, \mathrm{CaSO}_{4} \cdot 2 \mathrm{H}_{2} \mathrm{O}$, $\mathrm{FeSO}_{4} \cdot 7 \mathrm{H}_{2} \mathrm{O}$ and trace elements containing sulphur with $\mathrm{MgCl}_{2} \cdot 6 \mathrm{H}_{2} \mathrm{O}, \mathrm{CaCl}_{2} \cdot 6 \mathrm{H}_{2} \mathrm{O}$ and $\mathrm{FeCl}_{3} \cdot 6 \mathrm{H}_{2} \mathrm{O}$ to give final concentrations of $0 \cdot 1,0 \cdot 1$ and $0.001 \mathrm{~g}$./l., respectively. Preliminary experiments showed that the addition of chloride ion as $\mathrm{KCl}$ did not

\section{Table 1. The utilization of inorganic and organic sulphur compounds by Phytophthora species}

Highest yields expressed as percentages of yields from $\mathrm{Na}_{2} \mathrm{SO}_{4} \cdot 10 \mathrm{H}_{2} \mathrm{O}$ taken as 100 . Initial $\mathrm{pH}$ value for Phytophthora erythroseptica $(\mathrm{PE})$ and $P$. parasitica $(\mathrm{PP})=6 \cdot 6$; for $P$. infestans $(\mathrm{PI})=4.7$. Final $\mathrm{pH}$ values recorded in table. (Mg. dry wt. mycelium/flask average of 5 replicates. Incubation period for PI 16 days; those for PE and PP shown in brackets.)

\begin{tabular}{|c|c|c|c|c|c|c|}
\hline & & & Spec & & & \\
\hline Sulphur source & $\begin{array}{c}\text { Organism } \\
\text { PE } \\
\text { (mg. dry } \\
\text { wt./flask } \\
\text { and } \\
\text { incubation } \\
\text { time) }\end{array}$ & $\begin{array}{c}\text { Final } \\
\text { pH } \\
\text { value }\end{array}$ & $\begin{array}{c}\text { Organism } \\
\text { PP } \\
\text { (mg. dry } \\
\text { wt./flask } \\
\text { and } \\
\text { incubation } \\
\text { time) }\end{array}$ & $\begin{array}{c}\text { Final } \\
\text { pH } \\
\text { value }\end{array}$ & $\begin{array}{c}\text { Organism } \\
\text { PI } \\
\text { (mg. dry } \\
\text { wt./flask } \\
\text { at } \\
16 \text { days) }\end{array}$ & $\begin{array}{c}\text { Final } \\
\text { pH } \\
\text { value }\end{array}$ \\
\hline sulphate & $100(20)$ & $5 \cdot 8$ & $100(17)$ & $5 \cdot 7$ & 100 & $5 \cdot 8$ \\
\hline Im persulphate & $75(20)$ & $5 \cdot 8$ & $100(17)$ & $\mathbf{5 \cdot 5}$ & 24 & $3 \cdot 9$ \\
\hline metabisulphite & $124(25)$ & $5 \cdot 7$ & $110(17)$ & $5 \cdot 5$ & 29 & $4 \cdot 0$ \\
\hline dithionite & $100(25)$ & $5 \cdot 1$ & $90(17)$ & $5 \cdot 3$ & $\mathbf{3 3}$ & $4 \cdot 2$ \\
\hline thiosulphate & $81(20)$ & $5 \cdot 8$ & $100(17)$ & $5 \cdot 4$ & 100 & 6.0 \\
\hline sulphite & 124 (25) & $5 \cdot 8$ & 132 (13) & $5 \cdot 3$ & 81 & $5 \cdot 8$ \\
\hline ine hydrochloride & $115(25)$ & $5 \cdot 8$ & $98(17)$ & $\mathbf{5} \cdot \mathbf{3}$ & 43 & $5 \cdot 9$ \\
\hline e & $86(25)$ & $5 \cdot 7$ & 93 (17) & $5 \cdot 6$ & 95 & $5 \cdot 1$ \\
\hline 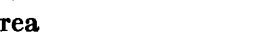 & $27(20)$ & $5 \cdot 9$ & $28(17)$ & $5 \cdot 4$ & 57 & $7 \cdot 3$ \\
\hline sulphide & $127(25)$ & $5 \cdot 7$ & $103(17)$ & $5 \cdot 4$ & 62 & $5 \cdot 6$ \\
\hline ilic acid & $20(20)$ & $6 \cdot 2$ & $15(13)$ & $5 \cdot 6$ & $\mathbf{5 7}$ & $6 \cdot 4$ \\
\hline ic acid & $26(20)$ & $5 \cdot 8$ & $14(13)$ & $5 \cdot 8$ & 43 & $4 \cdot 1$ \\
\hline ilamide & $10(25)$ & $6 \cdot 0$ & $16(13)$ & $5 \cdot 5$ & 57 & $7 \cdot 4$ \\
\hline alicylic acid & $18(25)$ & $6 \cdot 1$ & $22(9)$ & $5 \cdot 5$ & 19 & $\mathbf{3 . 9}$ \\
\hline onine & $110(25)$ & $5 \cdot 8$ & 104 (17) & $5 \cdot 4$ & 86 & $5 \cdot 7$ \\
\hline ide & $20(20)$ & $6 \cdot 2$ & $17(17)$ & $6 \cdot 0$ & $\mathbf{5 3}$ & $7 \cdot 5$ \\
\hline ol (no sulphur) & $17(20)$ & $6 \cdot 1$ & $16(17)$ & $5 \cdot 5$ & 24 & 4.7 \\
\hline
\end{tabular}

affect the growth of these fungi. The modified medium $\mathbf{A}$ was inoculated with organism PI and the medium B with organisms PE and PP as previously described. Organisms PE and PP were incubated at $28^{\circ}$ and PI at $20^{\circ}$. Dry weights of 5 replicate cultures were determined after 9,13 and 17 days of incubation for PP, after 15, 20 and 25 days for PE, and after 16 days for PI. The final $\mathrm{pH}$ values of 
the media were also determined. For organisms PE and PI there was a general increase in acidity varying between 0.4 and $1.5 \mathrm{pH}$ units, while for PI the increase in acidity was never greater than $0.8 \mathrm{pH}$ unit, but an increase in alkalinity as high as $2.8 \mathrm{pH}$ units was sometimes recorded. The results are shown in Table 1 which records the highest percentage yields expressed in terms of the yield from $\mathrm{Na}_{2} \mathrm{SO}_{4}$. $10 \mathrm{H}_{2} \mathrm{O}$ as $100 \%$. With $\mathrm{Na}_{2} \mathrm{SO}_{4} \cdot 10 \mathrm{H}_{2} \mathrm{O}$ the actual highest mycelial yields were $155 \mathrm{mg}$. after 17 days of incubation for organism PP, 94 mg. after 20 days for PE, and $21 \mathrm{mg}$ after 16 days for PI.

Since persulphate breaks down to sulphate very easily in solution, the results for potassium persulphate must be treated with reserve. In general, the results indicated that sodium sulphate and sodium thiosulphate were very good sulphur sources for all three fungi, while sodium metabisulphite, sodium dithionite, sodium sulphite, sodium sulphide, cystine and methionine were good sources for organisms PE and PP, but gave only moderate or poor mycelial yields with organism PI. Essentially similar observations were made by Fothergill \& Hide (1962) with four species of Pythium. Thus, in general, the oxidation level of the sulphur atom had no consistent significant effect on mycelial growth; a thiosulphate $\left(\mathrm{S}_{2} \mathrm{O}_{3}{ }^{2-}\right)$, a metabisulphite $\left(\mathrm{S}_{2} \mathrm{O}_{5}{ }^{2-}\right)$, a sulphite $\left(\mathrm{SO}_{3}{ }^{2-}\right)$ and a sulphate $\left(\mathrm{SO}_{4}{ }^{2-}\right)$ were all good sulphur sources. The yields from the sulphur-containing methionine and cystine were as high or nearly so, as the yields from the best inorganic sulphur sources in contrast to the findings of Volkonsky (1933) who worked with aquatic Saprolegniales. The other compounds used, particularly those containing a benzene ring (i.e. sulphanilic acid, thiazamide, sulphanilamide, sulphosalicylic acid), were very poor sulphur sources for all three fungi, except that moderate yields of mycelium were obtained with organism PI. These results are similar to those obtained by Steinberg (1941) with Aspergillus niger. No further correlation of structure with utilization could be made with the fungi used, thus emphasizing their ability to utilize a wide range of sulphurcontaining compounds. Preliminary experiments indicated that the metabolism of organisms PE and PP, as expressed by their nutritional requirements, was very similar and differed considerably from that of organism PI. The results with the sulphur compounds have emphasized this distinction. Organism PI shows a much narrower range of sulphur utilization than organisms PE and PP, but it seems to possess an ability to use compounds which are not used to any great extent by the other two fungi.

\section{The requirement for phosphorus}

The importance of phosphorus in the growth of fungi is, of course, well known, but few comparative studies on the use of different phosphates by species of Phytophthora have appeared in the literature. Hence an experiment was done to study the effects of different phosphates on mycelial production. In this experiment medium A was used in which potassium dihydrogen orthophosphate was replaced by $\mathrm{K}_{2} \mathrm{SO}_{4}, 0.67 \mathrm{~g}$. $/ 1$. To this medium were added singly in turn various phosphorus compounds to give a final concentration of phosphorus $0.3 \mathrm{~g} . / \mathrm{l}$. The medium was otherwise unbuffered at initial $\mathrm{pH} 4.7$ and the final $\mathrm{pH}$ value, recorded in each case, showed an increase in alkalinity of 1.0-1.5 pH units. As before, dry weights of 5 replicate cultures were determined after 9, 13 and 17 days of incubation for organism PP, after 15, 20 and 25 days for PE, and after 16 days for PI. The results are shown in Table 2 which records the highest mycelial yields expressed as a percentage 
of that for sodium dihydrogen orthophosphate taken as $100 \%$. With $\mathrm{NaH}_{2} \mathrm{PO}_{4}$ the actual highest mycelial yields were $148 \mathrm{mg}$. for organism PE after 25 days of incubation, $178 \mathrm{mg}$. for PP after 17 days, and $45 \mathrm{mg}$. for PI after 16 days.

For all organisms sodium dihydrogen orthophosphate, sodium metaphosphate and lecithin were excellent sources of phosphorus, while tetra-sodium pyrophosphate, sodium $\beta$-glycerophosphate and nucleic acid gave high yields with organisms PE and PP, but the corresponding yields for organism PI were greatly diminished. The highest comparative yields were obtained with lecithin for organism PE, and nucleic acid for organism PP but, as a whole, the inorganic phosphorus sources seemed to be better than the organic compounds. The remaining compounds gave poor yields of mycelium. There were not great differences in yield with favourable compounds but differences were noted in the rate of utilization of the compounds. For example, the two orthophosphates and sodium $\beta$-glycerophosphate were utilized much more rapidly than sodium metaphosphate or tetra-sodium pyrophosphate. Similar results have been recorded for species of Pythium by Hide (1961) and for Rhizopus stolonifera by Yeoman (1954). This suggests that orthophosphate is more readily available to these fungi and that metaphosphate and pyrophosphate are first converted in the mycelium to orthophosphate before they are utilized. Casein was a good source of phosphorus and gave visibly good mycelial growth but measurement was difficult because of heavy precipitation in the medium after incubation for 1 or 2 days; this precipitate was insoluble in water, $\mathrm{N}-\mathrm{HCl}$ or $\mathrm{H}_{2} \mathrm{SO}_{4}$ and dry weights were not recorded.

\section{Table 2. The utilization of various phosphorus compounds by Phytophthora species}

Highest yields expressed as percentages of yields from $\mathrm{Na}_{2} \mathrm{H}_{2} \mathrm{PO}_{4}$ taken as 100 . Initially all pH 4.7. (Mg. dry wt. mycelium/flask average of 5 replicates.)

\begin{tabular}{|c|c|c|c|}
\hline \multirow[b]{2}{*}{ Phosphorus source } & \multicolumn{3}{|c|}{ Organism } \\
\hline & $\begin{array}{l}\text { P. erythroseptica } \\
\text { (mg. dry wt./flask } \\
\text { and incubation } \\
\text { time, days) }\end{array}$ & $\begin{array}{l}P \text {. parasitica } \\
\text { (mg. dry wt./flask } \\
\text { and incubation } \\
\text { time, days) }\end{array}$ & $\begin{array}{c}P . \text { infestans } \\
\text { (mg. dry wt./flask } \\
\text { incubation time } \\
16 \text { days) }\end{array}$ \\
\hline lihydrogen orthophosphate & $100(25)$ & $100(17)$ & 100 \\
\hline aphosphate & $94(25)$ & $96(17)$ & 129 \\
\hline lium pyrophosphate & $101(25)$ & 97 (13) & 4 \\
\hline -glycerophosphate & $100(20)$ & $87(13)$ & 7 \\
\hline hosphite & $8(20)$ & $19(17)$ & 4 \\
\hline ypophosphite & $11(20)$ & 14 (13) & 13 \\
\hline id & $97(20)$ & 116 (17) & 49 \\
\hline & $119(20)$ & 77 (13) & 81 \\
\hline phosphate) & $\stackrel{+}{+}{ }_{23}^{(20)}$ & $11^{+}$ & $\begin{array}{c}+ \\
11\end{array}$ \\
\hline
\end{tabular}

\begin{tabular}{lrr} 
Sodium dihydrogen orthophosphate & $100(25)$ & $100(17)$ \\
Sodium metaphosphate & $94(25)$ & $96(17)$ \\
Tetra-sodium pyrophosphate & $101(25)$ & $97(13)$ \\
Sodium $\beta$-glycerophosphate & $100(20)$ & $87(13)$ \\
Sodium phosphite & $8(20)$ & $19(17)$ \\
Sodium hypophosphite & $11(20)$ & $14(13)$ \\
Nucleic acid & $97(20)$ & $116(17)$ \\
Lecithin & $119(20)$ & $77(13)$ \\
Casein & + & + \\
Control (no phosphate) & $23(20)$ & $11(13)$ \\
\multicolumn{2}{c}{ +, Good mycelial growth but weight not determinable. }
\end{tabular}

Factorial experiments

Some of the basal physical and chemical requirements of a culture medium for the growth of the organisms PE and PP having been determined, the effect of the balance of the chemicals used in the medium was next investigated. The factorial design and statistical analysis of the results should indicate whether or not a balance 
between the salts is necessary for high mycelial yields under the given experimental conditions. The direct effect of the individual salts in the medium and the interaction between them is also determined. Previous experiments showed that medium A was a satisfactory medium for organisms $\mathrm{PE}$ and $\mathrm{PP}$ but $\mathrm{KH}_{2} \mathrm{PO}_{4}$ was replaced by $\mathrm{K}_{2} \mathrm{HPO}_{4}$ at a concentration of $1.046 \mathrm{~g}$./l. to give initial solutions nearer to the $\mathrm{pH}$ growth optimum for these fungi. The solution was adjusted to $\mathrm{pH} \mathbf{6} \cdot 6$.

Initial factorial experiments showed that the highest concentrations of the salts were possibly limiting growth and this medium $\mathbf{A}$ was further modified to give basal concentrations of $\mathrm{K}_{2} \mathrm{HPO}_{4}$ at $1.568 \mathrm{~g}$./l., of $\mathrm{MgSO}_{4} .7 \mathrm{H}_{2} \mathrm{O}$ at $0.41 \mathrm{~g}$./l. and of $\mathrm{CaSO}_{4} \cdot 2 \mathrm{H}_{2} \mathrm{O}$ at $0 \cdot 414 \mathrm{~g}$./l. The new solutions were also adjusted to $\mathrm{pH} 6 \cdot 6$. In all experiments the final $\mathrm{pH}$ values of all replicates were determined; the variation of $\mathrm{pH}$ value was never more than one $\mathrm{pH}$ unit. The cultures were incubated at $28^{\circ}$ for $\mathbf{1 7}$ days for organisms PE and PP. The concentrations of the salts were fixed on the basis of halving and doubling those in the basal medium containing $\mathrm{K}_{2} \mathrm{HPO}_{4}$. Thus $\mathrm{K}_{2} \mathrm{HPO}_{4}, \mathrm{MgSO}_{4} \cdot 7 \mathrm{H}_{2} \mathrm{O}$ and $\mathrm{CaSO}_{4} \cdot 2 \mathrm{H}_{2} \mathrm{O}$ were each used at three concentrations and all possible combinations of them were set up, giving a total of 27 variations. Each combination was done in quintuplicate, thus, with each species of fungus, 135 culture flasks in each experiment were incubated. Each $150 \mathrm{ml}$. Erlenmeyer flask contained $30 \mathrm{ml}$. medium. The results given are the average $\mathrm{mg}$. dry wt./mycelium of 5 replicates. The grouped results are shown in Table 3 and the grouped analyses of variance are given in Table 4. For abbreviations of the salt concentrations used in the text below see Table 3 .

Table 3. Growth responses to two species of Phytophthora to different conditions of $\mathrm{K}_{2} \mathrm{HPO}_{4}, \mathrm{MgSO}_{4} .7 \mathrm{H}_{2} \mathrm{O}$ and $\mathrm{CaSO}_{4} .2 \mathrm{H}_{2} \mathrm{O}$

Concentration of $\mathrm{K}_{2} \mathrm{HPO}_{4}: \mathrm{P}_{1}, \mathrm{P}_{2}, \mathrm{P}_{3},=0.0045,0.009,0.018 \mathrm{~g}$. $/ 1$; of $\mathrm{MgSO}_{4}$. $7 \mathrm{H}_{2} \mathrm{O}: \mathrm{Mg}_{1}, \mathrm{Mg}_{2}, \mathrm{Mg}_{3}=0.0008,0.0016,0.0032 \mathrm{~g} . / \mathrm{l}$; of $\mathrm{CaSO}_{4} .2 \mathrm{H}_{2} \mathrm{O}: \mathrm{Ca}_{1}, \mathrm{Ca}_{2}$, $\mathrm{Ca}_{3}=0.0012,0.0024,0.0048 \mathrm{~g} . / \mathrm{l}$.

Difference required between means for significance at odds of $99: 1$ for $\mathrm{K}_{2} \mathrm{HPO}_{4}$, $\mathrm{MgSO}_{4} \cdot 7 \mathrm{H}_{2} \mathrm{O}$ and $\mathrm{CaSO}_{4} \cdot 2 \mathrm{H}_{2} \mathrm{O}=9.547 \mathrm{mg}$. for $P$. erythroseptica $(\mathrm{PE})$ and $6.518 \mathrm{mg}$. for $P$. parasitica (PP).

\begin{tabular}{|c|c|c|c|c|c|c|c|c|c|}
\hline \multicolumn{4}{|c|}{$\mathbf{P}_{1}$} & \multicolumn{3}{|c|}{$\mathbf{P}_{\mathbf{2}}$} & \multicolumn{3}{|c|}{$\mathbf{P}_{\mathbf{3}}$} \\
\hline $\mathrm{Mg}_{1}$ & $\mathbf{M}_{\xi}$ & $g_{2}$ & $\mathrm{Mg}_{3}$ & $\mathbf{M g}_{1}$ & $\mathbf{M g}_{2}$ & $\mathbf{M g}_{3}$ & $\mathbf{M g}_{1}$ & $\mathbf{M g}_{2}$ & $\mathbf{M g}_{3}$ \\
\hline PE PP & $\mathrm{PE}$ & $\mathbf{P P}$ & PE PP & $\begin{array}{r}\text { PE PP } \\
\text { Mean dry }\end{array}$ & $\begin{array}{l}\text { PE PP } \\
\text { wt. myce }\end{array}$ & $\begin{array}{l}\text { PE PP } \\
\text { elium/flask }\end{array}$ & PE PP & PE PP & PE PP \\
\hline $\begin{array}{ll}60 & 89\end{array}$ & 65 & 83 & $75 \quad 92$ & 118160 & 110172 & 120144 & 212178 & $192 \quad 174$ & $217 \quad 186$ \\
\hline $\begin{array}{rr}56 & 100 \\
80 & 98\end{array}$ & 66 & 90 & $\begin{array}{rr}70 & 92 \\
89 & 163\end{array}$ & $\begin{array}{ll}109 & 172 \\
123 & 102\end{array}$ & 117149 & $\begin{array}{rl}81 & 154\end{array}$ & $177 \quad 172$ & $149 \quad 191$ & $\begin{array}{ll}169 & 187 \\
165 & 174\end{array}$ \\
\hline
\end{tabular}

From the single salt analysis it is evident that there was no consistent result with all salts for both organisms. This analysis showed that the differences between mycelial dry weight with $\mathrm{K}_{2} \mathrm{HPO}_{4}$ were significant at all concentrations of the salt for both organisms, and in both cases the highest yield was obtained at the $\mathbf{P}_{1}$ level of the salt. For $\mathrm{MgSO}_{4} \cdot 7 \mathrm{H}_{2} \mathrm{O}$ with both organisms the differences observed between the $\mathrm{Mg}_{1}$ and $\mathrm{Mg}_{2}$ levels of this salt were significant. For organism PE the highest mean weight was obtained at the $\mathbf{M g}_{1}$ level, while for organism $\mathbf{P P}$ the $\mathbf{M g}_{\mathbf{2}}$ level 
gave the highest yield. For $\mathrm{CaSO}_{4} \cdot 2 \mathrm{H}_{2} \mathrm{O}$ with organism $\mathrm{PE}$ there were significant differences between the mean mycelial weights at the $\mathrm{Ca}_{1}$ and $\mathrm{Ca}_{2}$ level and also at the $\mathrm{Ca}_{2}$ and $\mathrm{Ca}_{3}$ levels, but not between the $\mathrm{Ca}_{1}$ and $\mathrm{Ca}_{3}$ levels of this salt. For organism PE these latter levels gave the same mycelial yield but for organism PP the highest mean yield was obtained with the $\mathrm{Ca}_{3}$ concentration.

Table 4. Analysis of variance (grouped) for Phytophthora erythroseptica (PE) and $\boldsymbol{P}$. parasitica $(\boldsymbol{P P})$

Required ' $F$ ' and ' $t$ ' values taken from Snedecor's tables (1946). Sums of squares and mean squares are omitted from table.

$F$ required odds

\begin{tabular}{|c|c|c|c|c|c|}
\hline \multirow[b]{3}{*}{ Variance } & \multirow[b]{3}{*}{ DF } & \multicolumn{4}{|c|}{$F$ required odds } \\
\hline & & \multicolumn{2}{|c|}{ Found organisms } & \multirow[b]{2}{*}{$99: 1$} & \multirow[b]{2}{*}{$19: 1$} \\
\hline & & organism PE & organism PP & & \\
\hline Total & 134 & - & 一 & 一 & 一 \\
\hline $\mathrm{CaSO}_{4} \cdot 2 \mathrm{H}_{2} \mathrm{O}$ & 2 & $20 \cdot 12$ & $\mathbf{2 \cdot 5 3}$ & $4 \cdot 88$ & $\mathbf{3} \cdot \mathbf{1 1}$ \\
\hline $\mathrm{K}_{\mathbf{8}} \mathrm{HPO}_{4}$ & 2 & $5419 \cdot 19$ & $\mathbf{3 2 5} \cdot 55$ & $4 \cdot 88$ & $3 \cdot 11$ \\
\hline $\mathrm{MgSO}_{4} \cdot 7 \mathrm{H}_{2} \mathrm{O}$ & 2 & $64 \cdot 66$ & $60 \cdot 61$ & $4 \cdot 88$ & $3 \cdot 11$ \\
\hline $\mathrm{CaSO}_{4} \times \mathrm{K}_{2} \mathrm{HPO}_{4}$ & 4 & $25 \cdot 48$ & $50 \cdot 99$ & $\mathbf{3 \cdot 5 6}$ & $2 \cdot 49$ \\
\hline $\mathrm{K}_{2} \mathrm{HPO}_{4} \times \mathrm{MgSO}_{4}$ & 4 & $94 \cdot 25$ & $72 \cdot 41$ & $\mathbf{3 \cdot 5 6}$ & $2 \cdot 49$ \\
\hline $\mathrm{CaSO}_{4} \times \mathrm{MgSO}_{4}$ & 4 & $4 \cdot 54$ & $\mathbf{3 6} \cdot 73$ & $\mathbf{3 \cdot 5 6}$ & $2 \cdot 49$ \\
\hline $\mathrm{K}_{2} \mathrm{HPO}_{4} \times \mathrm{MgSO}_{4} \times \mathrm{CaSO}_{4}$ & 8 & $7 \cdot 13$ & 23.12 & $2 \cdot 74$ & $2 \cdot 06$ \\
\hline Residual error & 108 & - & - & - & - \\
\hline
\end{tabular}

The grouped analyses of variance showed that there were significant interactions between all the salts in the first order combinations for both organisms. These results show that there was a physiological balance in some cases between these salts under the given conditions. With organism $\mathrm{PE}$ the interaction between $\mathrm{K}_{2} \mathrm{HPO}_{4}$ and $\mathrm{MgSO}_{4} \cdot \mathbf{7 H}_{2} \mathrm{O}$ showed that at the $\mathbf{P}_{1}$ and $\mathbf{P}_{2}$ levels increasing the concentration of $\mathrm{MgSO}_{4} \cdot 7 \mathrm{H}_{2} \mathrm{O}$ had only a small effect. The highest yield was obtained with the highest concentration of $\mathrm{K}_{2} \mathrm{HPO}_{4}$ and the lowest concentration of $\mathrm{MgSO}_{4}$. $7 \mathrm{H}_{2} \mathrm{O}$; no balance is indicated. But with organism PP similar dry weights were obtained at the $P_{1}$ and $P_{3}$ levels with the $\mathrm{Mg}_{1}$ level and, in general, increasing the concentration of $\mathrm{K}_{2} \mathrm{HPO}_{4}$ led to increasing yields relative to an increasing level of $\mathrm{MgSO}_{4} \cdot \mathrm{rH}_{2} \mathrm{O}$; a balance between the salts is indicated. The interaction of $\mathrm{MgSO}_{4}$. ${ }_{7} \mathrm{H}_{2} \mathrm{O}$ and $\mathrm{CaSO}_{4} \cdot 2 \mathrm{H}_{2} \mathrm{O}$ is significant but there were only relatively small gross differences between the yields of $\mathrm{PE}$. The highest yields were obtained with the $\mathrm{Mg}_{1}$ and $\mathrm{Ca}_{3}$ levels and with $\mathrm{Mg}_{3}$ and $\mathrm{Ca}_{1}$ levels. The $\mathrm{Ca}_{2}$ levels did not show any consistent change in yield with increasing concentration of $\mathrm{MgSO}_{4} \cdot 7 \mathrm{H}_{2} \mathrm{O}$. With organism PP the interaction of these two salts is interesting. At the $\mathrm{Ca}_{1}$ and $\mathrm{Ca}_{2}$ levels, increasing the $\mathrm{MgSO}_{4} \cdot 7 \mathrm{H}_{2} \mathrm{O}$ concentration had little effect on yield and there were no significant differences between them, but with the $\mathrm{Ca}_{3}$ level there appeared to be inhibition of growth with the lowest concentration of $\mathrm{MgSO}_{4} \cdot 7 \mathrm{H}_{2} \mathrm{O}$. Doubling the amount of this salt in the medium gave a great increase in mycelial yield which was maintained, but not improved, by further increase in concentration of $\mathrm{MgSO}_{4} \cdot 7 \mathrm{H}_{2} \mathrm{O}$. A balance between these two salts is necessary and seems to be operative in the ratio of $2 \mathrm{CaSO}_{4} \cdot 2 \mathrm{H}_{2} \mathrm{O}: 1 \mathrm{MgSO}_{4} \cdot 7 \mathrm{H}_{2} \mathrm{O}$. With organism PE the interaction between $\mathrm{K}_{2} \mathrm{HPO}_{4}$ and $\mathrm{CaSO}_{4} \cdot 2 \mathrm{H}_{2} \mathrm{O}$ showed that at the $\mathrm{P}_{1}, \mathrm{P}_{2}$ and $\mathrm{P}_{3}$ levels there was increasing yield with increasing concentration of $\mathrm{CaSO}_{4} \cdot 2 \mathrm{H}_{2} \mathrm{O}$, but 
at the $\mathbf{P}_{1}$ level the highest yield was given with the $\mathbf{C a}_{3}$ level, while at the $\mathbf{P}_{\mathbf{3}}$ level it was given with the $\mathrm{Ca}_{1}$ level. With organism $\mathrm{PP}$ at the $\mathrm{Ca}_{3}$ level there was no consistent growth increase with increasing $\mathrm{K}_{2} \mathrm{HPO}_{4}$ concentration and the highest yield was obtained at the $\mathrm{P}_{3}$ and $\mathrm{Ca}_{2}$ levels. The yields were nearly identical at the $\mathbf{P}_{1} \mathrm{Ca}_{3}, \mathbf{P}_{2} \mathrm{Ca}_{3}$ and $\mathrm{P}_{3} \mathrm{Ca}_{3}$ levels. Thus a balance is indicated.

The analysis of variance also showed that the interaction of all three salts was significant for both organisms. The concentration of $\mathrm{K}_{2} \mathrm{HPO}_{4}$ was here the most important factor controlling the yield of the organism PE. The highest yields were obtained at the $P_{3}$ level. At the $P_{1}$ level increasing the concentration of the other two salts only affected the yield slightly. At the $\mathbf{P}_{\mathbf{3}}$ and $\mathrm{Ca}_{3}$ levels high yields were only obtained when the $\mathrm{MgSO}_{4} \cdot 7 \mathrm{H}_{2} \mathrm{O}$ concentration was low. With organism PP there was little difference between the mean mycelial yields at the $\mathbf{P}_{2} \mathbf{M g}_{1} \mathbf{C a}_{2}$ and $\mathbf{P}_{3} \mathrm{Mg}_{2} \mathrm{Ca}_{3}$ levels. There was a consistently increasing yield as the concentration of the salts was increased proportionately from the $\mathbf{P}_{1} \mathrm{Mg}_{2} \mathrm{Ca}_{1}, \mathrm{P}_{2} \mathrm{Mg}_{2} \mathrm{Ca}_{2}$ and the $\mathbf{P}_{3} \mathrm{Mg}_{3} \mathrm{Ca}_{3}$ levels. The highest mean weight of $191 \mathrm{mg}$. was obtained at the $\mathbf{P}_{3} \mathrm{Mg}_{2}$ $\mathrm{Ca}_{2}$ level, but weights of 186,187 and $181 \mathrm{mg}$. were also obtained at the $\mathrm{P}_{3} \mathrm{Mg}_{3} \mathrm{Ca}_{1}$, $\mathrm{P}_{3} \mathrm{Mg}_{3} \mathrm{Ca}_{2}$ and $\mathrm{P}_{1} \mathrm{Mg}_{2} \mathrm{Ca}_{3}$ levels, respectively, suggesting that the concentration is not so important when the other two salts are in a relatively high concentration in the approximate ratio of $2 \mathrm{CaSO}_{4} \cdot 2 \mathrm{H}_{2} \mathrm{O}: 1 \mathrm{MgSO}_{4} \cdot 7 \mathrm{H}_{2} \mathrm{O}$.

\section{Balance between $\mathrm{MgSO}_{4} \cdot 7 \mathrm{H}_{2} \mathrm{O}$ and $\mathrm{CaSO}_{4} \cdot 2 \mathrm{H}_{2} \mathrm{O}$}

The previous experiments indicated that there was a physiological balance between $\mathrm{K}_{2} \mathrm{HPO}_{4}$ and $\mathrm{CaSO}_{4} \cdot 2 \mathrm{H}_{2} \mathrm{O}$. While balance has been shown to exist between various combinations of salts by different workers, this would seem to be the first time a balance has been indicated between these two salts. To confirm this result another experiment was designed to test the change in the amount of growth which might result when the concentrations of the salts were varied while still maintaining the balance between them. This experiment was designed factorially following the method of Talley \& Blank (1941) and Fothergill \& Ashcroft (1955). Thus the basic concentrations of $\mathrm{MgSO}_{4} \cdot 7 \mathrm{H}_{2} \mathrm{O}$ and $\mathrm{CaSO}_{4} \cdot 2 \mathrm{H}_{2} \mathrm{O}$ were $0 \cdot 205$ and $0.414 \mathrm{~g}$./l., respectively; these were decreased to half in one set of solutions and increased twice and then four times in other solutions. This gave four treatments each having the same balance between the salts but the ratio of their concentrations was $0 \cdot 5: 1: 2: 4$. Each of these four solutions was tested singly with $\mathrm{K}_{2} \mathrm{HPO}_{4}$ at $2 \cdot 091,3 \cdot 136,4 \cdot 181$ and $5 \cdot 227 \mathrm{~g}$./ 1 ., respectively, giving 16 solutions in all. The remaining ingredients of the basal medium remained the same. The medium was adjusted initially to $\mathrm{pH} 6 \cdot 6$ and the cultures incubated in 4-replicate at $28^{\circ}$ for 11 days. The results expressed as mg. mean dry wt. mycelium per flask are shown in Table 5 where treatments are numbered 1-16 in parentheses.

The results showed that the mean mycelial yields for $\mathrm{K}_{2} \mathrm{HPO}_{4}$ at the $\mathbf{P}_{1}, \mathbf{P}_{2}, \mathbf{P}_{3}$ and $\mathbf{P}_{4}$ levels were not significantly different from each other but they were different from the yields at the $\mathrm{Mg}_{1}$ and $\mathrm{Ca}_{1}$ levels. To show the interaction of $\mathrm{MgSO}_{4} \cdot 7 \mathrm{H}_{2} \mathrm{O}$ and $\mathrm{CaSO}_{4} \cdot \mathbf{2} \mathrm{H}_{2} \mathrm{O}$ ' $t$ ' tests were performed. There were no significant differences between treatments 2,3 and 4 at the $P_{1}$ level, but there was between treatments 1 and 2. At all other concentrations of $\mathrm{K}_{2} \mathrm{HPO}_{4}$ a similar pattern was shown, that is, there were no significant differences between treatments 6,7 and 8 , treatments 10,11 and 12, and treatments 14,15 and 16 ; but at the $P_{2}, P_{3}$ and $P_{4}$ levels, respec- 
tively, there were significant differences between treatments 14, 15 and 16. At the $\mathbf{P}_{2}, \mathbf{P}_{3}$ and $\mathbf{P}_{4}$ levels, respectively, there were significant differences between treatments 5 and 6, 9 and 10, 13 and 14 at these levels of $\mathrm{K}_{2} \mathrm{HPO}_{4}$. These results confirm

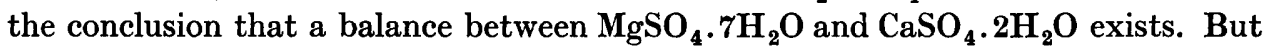
since significantly different mean dry weights were recorded with the $\mathrm{Mg}_{1}$ and $\mathrm{Ca}_{1}$ levels at all levels of $\mathrm{K}_{2} \mathrm{HPO}_{4}$, it is evident that the effect of the balance between $\mathrm{MgSO}_{4} \cdot \mathbf{7 H}_{2} \mathrm{O}$ and $\mathrm{CaSO}_{4} \cdot \mathbf{2} \mathrm{H}_{2} \mathrm{O}$ operated only after a certain concentration of the salts had been reached. Thereafter the concentration of either of these salts could be varied without affecting the mycelial yield of Phytophthora parasitica, provided that the concentration of the other salt is varied proportionately.

Table 5. Mean dry weights and growth responses of Phytophthora parasitica after 11 days incubation at $28^{\circ}$ on media with the same balance but with different concentrations of certain components

Concentrations of $\mathrm{K}_{2} \mathrm{HPO}_{4}: \mathrm{P}_{1}, \mathbf{P}_{2}, \mathrm{P}_{3}, \mathrm{P}_{4}=2 \cdot 091,3 \cdot 136,4 \cdot 181,5 \cdot 227 \mathrm{~g} . / \mathrm{l}$; of $\mathrm{MgSO}_{4} \cdot 7 \mathrm{H}_{2} \mathrm{O}: \mathrm{Mg}_{1}, \mathrm{Mg}_{2}, \mathrm{Mg}_{4}, \mathrm{Mg}_{4}=0 \cdot 102,0 \cdot 205,0.410,1.620 \mathrm{~g} . / 1$; of $\mathrm{CaSO}_{4}$. $2 \mathrm{H}_{2} \mathrm{O}: \mathrm{Ca}_{1}, \mathrm{Ca}_{2}, \mathrm{Ca}_{3}, \mathrm{Ca}_{4}=0.202,0.414,0.828,1.656 \mathrm{~g} . / 1$. ' $t$ ' $=2.447$ for 6 degrees of freedom at $\boldsymbol{P}=\mathbf{0 . 0 5}$; values of ' $t$ ' for combinations of treatments, $1 \times \mathbf{2}=$ $4.063,2 \times 3=0.390,3 \times 4=0.917,5 \times 6=7 \cdot 170,6 \times 7=0.780, \quad 7 \times 8=1 \cdot 764$, $9 \times 10=4 \cdot 176,10 \times 11=0 \cdot 258,11 \times 12=0 \cdot 249,13 \times 14=17 \cdot 159,14 \times 15=0.599$, $15 \times 16=0.532$. Figures in brackets are treatment numbers, i.e. $1-16$, referred to in text.

$\begin{array}{llllc}\mathrm{Mg}_{1} & \mathrm{Mg}_{2} & \mathrm{Mg}_{3} & \mathrm{Mg}_{4} & \text { Mean } \\ \mathrm{Ca}_{1} & \mathrm{Ca}_{2} & \mathrm{Ca}_{3} & \mathrm{Ca}_{4} & \mathrm{~N}\end{array}$

Mean dry wt. mycelium (mg./flask)

$\begin{array}{lrllll}P_{1} & 114(1) & 152(2) & 154(3) & 140(4) & 140 \\ P_{2} & 97(5) & 173(6) & 162(7) & 143(8) & 143 \cdot 7 \\ P_{3} & 106(9) & 141(10) & 144(11) & 146(12) & 134 \cdot 2 \\ P_{4} & 92(13) & 166(14) & 157(15) & 147(16) & 140 \cdot 5\end{array}$

General mean $=139.6 \mathrm{mg}$. dry wt. mycelium $/$ flask.

\section{CONCLUSION}

In general, the results of the factorial experiments showed that there was a considerable difference between the nutritional requirements of Phytophthora erythroseptica (PE) and $P$. parasitica (PP). With the individual salts used in the medium the greatest effect on mycelial growth was produced by varying the concentration of $\mathrm{K}_{2} \mathrm{HPO}_{4}$ for both organisms. Results for the other two salts were more variable and significant differences in dry weights did not vary in any general way. An absolute balance between the major mineral nutrients studied was not shown for $\boldsymbol{P}$. erythroseptica but was shown for all combinations of salts with $\boldsymbol{P}$. parasitica. The latter fungus seems to have more specific nutritional requirements than the former. The interaction of $\mathrm{CaSO}_{4} \cdot 2 \mathrm{H}_{2} \mathrm{O}$ and $\mathrm{MgSO}_{4} \cdot 7 \mathrm{H}_{2} \mathrm{O}$ at higher concentrations was outstanding for $P$. parasitica. Although the omission of $\mathrm{CaSO}_{4}$. $\mathbf{2} \mathrm{H}_{2} \mathrm{O}$ from the original medium $\mathrm{A}$ had only a small effect on growth, the increase in acidity of the unbuffered medium during growth was great. Hence the interactions of $\mathrm{CaSO}_{4} \cdot 2 \mathrm{H}_{2} \mathrm{O}$ and $\mathrm{MgSO}_{4} \cdot 7 \mathrm{H}_{2} \mathrm{O}$ may only occur at, or near to, the optimum growth $\mathrm{pH}$ for $\boldsymbol{P}$. parasitica. Second-order interactions between three salts were demonstrated. 
The results for Phytophthora erythroseptica and $\boldsymbol{P}$. parasitica support the findings of other workers. For example, Talley \& Blank (1941), Fothergill \& Ashcroft (1955) and Fothergill \& Hide (1962) found that a physiological balance between mineral salts in the medium was necessary for good growth of the fungal parasites Phymatotrichum omnivorum and Venturia inaequalis, and the two species Pythium debaryanum and $\boldsymbol{P}$. ultimum. No balance, however, was required for $\boldsymbol{P}$. afertile and $\boldsymbol{P}$. torulosum. The highest mycelial yields $(237 \mathrm{mg}$. for organism $\boldsymbol{P}$. erythroseptica and $191 \mathrm{mg}$. for $\boldsymbol{P}$. parasitica) were obtained with the modified liquid basal medium $\mathbf{A}$ containing glucose, $25 \mathrm{~g}$./l.; DL-asparagine, 4.0 g./l.; $\mathrm{FeSO}_{4} .7 \mathrm{H}_{2} \mathrm{O}, 0.001 \mathrm{~g} . / 1$; thiamine, $0 \cdot 8 \mathrm{mg}$./l.; $\mathrm{ZnSO}_{4} .7 \mathrm{H}_{2} \mathrm{O}$, 1 p.p.m.; $\mathrm{H}_{2} \mathrm{MoO}_{4}$ and $\mathrm{CuSO}_{4} .5 \mathrm{H}_{2} \mathrm{O}, 2$ p.p.m. with $\mathrm{K}_{2} \mathrm{HPO}_{4}, 0.018$ g./l.; $\mathrm{MgSO}_{4} .7 \mathrm{H}_{2} \mathrm{O}, 0.0008$ g./l.; and $\mathrm{CaSO}_{4} .2 \mathrm{H}_{2} \mathrm{O}, 0.0048$ g./l. for organism PE and $\mathrm{K}_{2} \mathrm{HPO}_{4}, 0.018 \mathrm{~g}$./l.; $\mathrm{MgSO}_{4} .7 \mathrm{H}_{2} \mathrm{O}, 0.0016 \mathrm{~g}$./l., and $\mathrm{CaSO}_{4} \cdot 2 \mathrm{H}_{2} \mathrm{O}, 0.0024 \mathrm{~g}$./l. for $P$. parasitica. Phytophthora infestans has the most exacting nutritional requirements but grows satisfactorily on fewer sulphur and phosphorus compounds than either $\boldsymbol{P}$. parasitica or $\boldsymbol{P}$. erythroseptica. Mycelial yields of $\boldsymbol{P}$. infestans were also very much less than those for the other fungi for all variations tried of the two basal media $A$ and $B$. The highest mycelial yield for $\boldsymbol{P}$. infestans was only $58 \mathrm{mg}$. and was obtained with medium A above but containing $\mathrm{K}_{2} \mathrm{SO}_{4}, 0 \cdot 67 \mathrm{~g}$./l. and $\mathrm{NaPO}_{3}, 0 \cdot 3 \mathrm{~g}$./l. in place of $\mathrm{K}_{2} \mathrm{HPO}_{4}$.

\section{REFERENCES}

Cantino, E. C. (1955). Physiology and phylogeny in the water moulds. Quart. Rev. Biol. 30, 138.

Fothergill, P. G. \& Ashcroft, R. (1955). The nutritional requirements of Venturia inaequalis. J. gen. Microbiol. 12, 387.

Fothergill, P. G. \& Hide, D. (1962). Comparative nutritional studies of Pythium species. J. gen. Microbiol. 29, 325.

Fothergill, P. G. \& Jones, M. (1958). Nutritional studies of some Zygorhynchus species. J. gen. Microbiol. 19, 298.

Fothergilu, P. G. \& RaIne, L. C. D. P. (1954). The mineral nutritional requirements of Mucor hiemalis Wehm. J. gen. Microbiol. 10, 17.

Fothergitx, P. G. \& Yeoman, M. M. (1957). The mineral nutrition of Rhizopus stolonifera. J.gen. Microbiol. 17, 631.

Hall, A. M. (1959). The culture of Phytophthora infestans in artificial media. Trans. Brit. mycol. Soc. 42, 15.

Hide, D. (1961). Nutritional studies on some members of the genus Pythium. Thesis. University of Durham.

Lopatecki, L. E. \& Newton, W. (1956). The nutrition of Phytophthora. Can. J. Bot. 34, 151.

Merrotra, B. S. (1950). Physiological studies on some members of the genus Phytophthora. 2. Sulphur requirements. Allahabad Univ. Stud.

Payette, E. \& Perrault, C. (1944). Action de la thiamine sur le Phytophthora infestans (Mont.) de Bary. Can. J. Res. (Sect. C, Bot. Sci.), 22, 127.

Robrins, W. J. (1937). The assimilation by plants of various forms of nitrogen. Am.J. Bot. 24, 243.

Sakai, R. (1955). Physiological studies on Phytophthora infestans (Mont.) de Bary, part 2, Nitrogen sources. Ann. phytopath. Soc. Japan, 19, 141.

SaKaI, R. (1956). Physiological studies of Phytophthora infestans (Mont.) de Bary, part 1. Abstr. Rev. Mycol. 70, 99.

Snedecor, G. W. (1946). Statistical Methods, 4th ed. Iowa State College Press. 
Steingerg, R. A. (1941). Sulphur and trace element nutrition of Aspergillus niger. J. agric. Res. 63, 109.

Talley, P. J. \& Blank, L. M. (1941). A critical study of the nutritional requirements of Phymatotrichum omnivorum. Plant Physiol. 16, 1.

Volkonsky, M. (1933). Sur l'assimilation des sulphats par les champignons. Annls Inst. Pasteur, Paris, 50, 703.

YeOMAN, M. M. (1954). The mineral nutrition and phosphorus metabolism of Rhizopus stolonifera. Thesis. University of Durham. 